DOI https://doi.org/10.18551/rjoas.2017-08.01

\title{
CORPORATE SOCIAL RESPONSIBILITY DISCLOSURE AND CORPORATE FINANCIAL PERFORMANCE: A META-ANALYSIS
}

\author{
Prasetya Heru Dwi*, Saraswati Erwin, Ghofar Abdul \\ Faculty of Economics and Business, University of Brawijaya, Malang, Indonesia \\ *E-mail: herudwiprasetya@gmail.com
}

\begin{abstract}
This study aims to determine the effect of Corporate Social Responsibility Disclosure (CSRD) and corporate financial performance. This research use meta analysis with 60 sample of research result in Indonesia. The results of this study indicate that in general CSRD can improve the corporate financial performance. The relationship between CSRD and the corporate financial performance is weakened by one of the financial performance measurement models. Thus, the results of this study found that the influence of CSRD on corporate financial performance can be different due to differences in financial performance measurement model corporate.
\end{abstract}

\section{KEY WORDS}

Corporate social responsibility disclosure, corporate financial performance, meta-analysis.

The main purpose of the establishment of a corporate is to improve the welfare of shareholders. This welfare can be improved through good corporate performance. Corporate performance is divided into two types namely financial performance and non-financial performance. The financial performance of the corporate is an important factor to assess the overall performance of the corporate itself, because the financial performance is the results achieved by the corporate has been in accordance with the planning (Muntiah, 2013), and serves as a measure of the level of achievement of corporate goals and tools to decision making (Armstrong, 2014).

In making an economic decision, investors not only rely on the financial performance of the corporate but also require non-financial information in the process of making investment decisions. Investors include variables related to social issues and environmental sustainability. Investors tend to invest in corporate that have good business ethics, employees, care about environmental impacts, and have corporate social responsibility with stakeholders (Belkaoui, 1976 and Patten, 1990). Sustainability reporting is one of the reports that provide non-financial information (Eipstein and Freedman, 1994). Sustainability reporting is increasingly becoming a trend and a need for progressive corporate to inform their economic, social and environmental performance as well as to stakeholders of the corporate (Chariri, 2009).

Research on corporate social responsibility disclosure and corporate finance performance has been done. In Indonesia itself also has a lot of research that examines the relationship between CSRD and the financial performance of the corporate. However, there are different results from the studies that have been done. Some researchers suggest that CSRD can improve the corporate financial performance (Ahmed et al., 2012; Dahlia and Siregar, 2008; Purnomo and Widianingsih, 2012; Pustikaningsih, 2011). Other researchers argue that CSRD tends to reduce the corporate financial performance (Criso'stomo et al., 2011; Indrawan, 2011). Some researchers argue that CSRD has no effect on financial performance (Anggraini, 2006, Athanasia and Maria, 2010; Wijayanti et al., 2011; Yaparto et al., 2013).

Because of various findings and results in finding accurate conclusions on CSRD relationships with financial performance. This study aims to examine the relation of CSRD on the corporate financial performance and analyze the relationship is moderated by CSRD measurement model or corporate financial performance by using meta analysis. 


\section{LITERATURE REVIEW AND HYPOTHESES}

Financial Performance. Financial performance is the results achieved by the corporate has been in accordance with the planning (Muntiah, 2013). Financial performance is an important thing, because it serves as a measure of the level of achievement of corporate goals and tools to determine in making decisions (Armstrong, 2014). Financial performance also means an analysis conducted to see how far a corporate has been operating properly and properly (Fahmi, 2011). Another understanding of financial performance is the corporate ability to manage and control its own resources (IAI, 2007).

Legitimacy Theory. Legitimacy is a psychological state of people's and group's alignments to the environment. The legitimacy of a corporate can be seen as a given by society to the corporate and something the corporate wants or sought from society (O'Donovan, 2002). Community legitimacy is an important factor for the corporate to develop the corporate in the future (Hadi, 2014), so that the corporate will continue to grow if the community realizes that the corporate operates in accordance with the values and norms is exist.

Corporate activity should be in accordance with the social value of its environment, in order to gain legitimacy support from the community, in accordance with the existing system in society and make reporting activities that reflect social values (Dowling and Pfeffer, 1975). For legitimacy to be more effective, companies must communicate with the public continuosly. Communication will build perceptions about the corporate, also do the disclosure, especially related to social responsibilities (Patten, 1990).

Stakeholders Theory. Stakeholder theory, which is the theory that describes to whichever corporate is responsible (Freeman, 1983). The sustainability of a corporate's operations depends on the its ability to balance the diverse interests of its stakeholders. Companies capable of reaching stakeholder support, then market share, sales, and corporate profits will increase (Angela, 2015).

Corporate Social Responsibility. Corporate Social Responsibility (CSR) is a concept of social responsibility to show the public about the social activities of the corporate and its effects on society by considering the long-term sustainability of the corporate (Gray et al., 1995). CSR also means the corporate's commitment to contribute to sustainable economic development with due regard to corporate social responsibility and focuses on the balance between attention to economic, social and environmental aspects (Untung, 2009).

Social responsibility is a form of corporate concern for the external environment in which the corporate operates by engaging various activities undertaken with the aim of conserving or preserving the environment, community norms, participation in development, and other forms of social responsibility. CSR is identical with sustainability development like corporate in carrying out operational activities should be based on decisions that are not based on financial factors but on the basis of social and environmental factors for the moment as well as for the long term (Jamali, 2014).

Research Hypotheses. Considering about the previous literates, we expected the corporate social responsibility disclosure positively affects the corporate financial performance $(\mathrm{H} 1)$. The relationship of corporate social responsibility disclosure on corporate financial performance is moderated by CSRD measurement model $(\mathrm{H} 2)$. The relationship of corporate social responsibility disclosure on the corporate financial performance is moderated by the corporate financial performance measurement model $(\mathrm{H} 3)$.

\section{DATA AND METHODS OF RESEARCH}

The approach used in this study is by literature review which means to examine the results of research on the impact of corporate social responsibility disclosure on the corporate financial performance. The analytical tool used is a meta-analysis that aims to combine several similar research on the influence of CSRD on the corporate financial performance. Meta analysis is done by collecting previous research results with the same 
topic, then statistical results are processed to determine the effect size of CSRD with financial performance which will be used for moderation effect analysis.

Meta Analysis. Meta-analysis is a statistical technique for combining the results of two or more similar studies, to obtain a quantitative data summary (Anwar, 2005). In addition, meta-analysis is good for understanding the research literature by assessing the overall effect of existing research (Hunter and Schmidt, 1990). Thus, the meta-analysis technique is the most effective way to summarize, integrate, and interpret some of the results of research with a statistical approach to one area of science, or it may be called "an analysis performed on other analyzes already performed". The studies that have been conducted tend to have varied results such as having different sample sizes, time periods, and research methods (Glass, 1978).

Sensitivity Analysis. Sensitivity analysis is an analysis used to assess whether one meta-analysis result is relatively stable to the effect of change or not. These influences include research design, geographic location, time period, and quality of studies (Fanani, 2016). Meta-analysis studies allow for publication bias. In this study, the possible bias in the type of data sample research, the research published or unpublished. Sensitivity analysis attempts to answer whether there is a moderating effect on the publication status on the relationship between CSRD and the corporate financial performance.

\section{EMPIRICAL RESULTS AND DISCUSSION}

During the study period (2000-2016), 151 articles were collected according to the topic of CSRD's influence on the corporate financial performance. The study was then selected to find research with complete data in accordance with the needs of meta analysis. After going through the selection, 60 research samples are collected according to required criteria. The research is not included in the criteria because the research does not include the data required in the meta analysis, ie the number of samples, the operational variables, the statistical value $r$, and the statistical values that can be converted to $r$ (t-statistics, F-statistics, and p-value).

Table 1 - Sample Selection

\begin{tabular}{|c|l|c|}
\hline No. & Criteria & Total \\
\hline 1 & CSRD and corporate financial performance articles & 151 articles \\
\hline 2 & Required statistical data such as n, t and F are not available one or more. & $(91)$ articles \\
\hline \multicolumn{2}{|c|}{ Total Sample } & 60 articles \\
\hline
\end{tabular}

These studies use a variety of measurement models to measure both the dependent variable (financial performance) and the independent variables of Corporate Social Responsibility (CSRD). CSRD with measurement of Corporate Social Responsibility Index (CSRDi) and PROPER SRI KEHATI (Environmental Performance) index. Financial Performance with measurement Return On Equity (ROE), Return On Assets (ROA), Stock Return, Earning Per Share (EPS), and Profit Persistence.

The effect size in the meta-analysis is used to represent the findings of the sampled studies. Statistical data from each research in the form of r-statistics is included into effect size in the meta analysis. If r-statistics are not found, then t-statistics, F-statistics, and pvalues can be converted to r-statistics. In this research, there are no research samples that show r-statistics, so that the conversion of t-statistics and F-statistics to r-statistics is done. A total of 56 studies used t-statistics transformation to r-statistics, while 4 studies used transformation of F-statistics to r-statistics.

Meta Analysis on Explanatory Variable. Explanatory variable in this research using CSRD variable. Based on the results of meta analysis in Table 5.1, from 60 studies that examine the influence of CSRD on the corporate financial performance, the average correlation $(\bar{r})=0.1820$ with confidence interval of $95 \%(0.0858-0.2782)$. These results show that CSRD has a significant positive effect on the corporate financial performance, so it can be said that hypothesis $1(\mathrm{H} 1)$ is accepted. 
Table 2 - Meta-Analysis Result (General Meta Analysis)

\begin{tabular}{|c|c|c|c|c|c|c|c|}
\cline { 2 - 8 } \multicolumn{1}{c|}{} & $\sum \mathrm{Ni}$ & $\mathrm{K}$ study & $\mathrm{r}$ & Min & to & Max & $\mathrm{x}_{\mathrm{k}-1}^{2}$ \\
\hline General Meta Analysis & 6630 & 88 & 0,1820 & 0,0858 & - & 0,2782 & 436,0571 \\
\hline
\end{tabular}

Based on the calculation of Chi Square (X2k-1), obtained value 436,0571. The value is greater than the value of Chi Square table (X20.01), which is 88.379. This indicates a moderation effect that affects the relationship between CSRD and the corporate financial performance. Therefore, to know the existence of moderation effects, sub-group analysis of CSRD measurement and financial performance model is required.

Meta Analysis of Moderator Effect. Based on the results of Chi Square test that has been done before, the value of Chi Square statistic is greater than the value of Chi Square table (X2k-1> X20,01), so there is a moderation effect between CSRD and corporate financial performance. Table 5.2. Explains the effects of moderation with financial performance measurement models and CSRD measurement models.

Table 3 - Meta-Analysis Result (Meta Sub-group)

\begin{tabular}{|c|c|c|c|c|c|c|c|c|}
\hline & & $\sum \mathrm{Ni}$ & K study & $\mathrm{r}$ & Min & to & $\operatorname{Max}$ & $\mathrm{x} 2$ \\
\hline & General Meta Analysis & 6630 & 88 & 0,1820453 & 0,0858575 & - & 0,2782330 & 436,0571951 \\
\hline \multirow{2}{*}{$\begin{array}{l}\text { 充 } \\
\text { 出 } \\
\text { 岀 } \\
\underline{\mathrm{O}}\end{array}$} & CSRDi & 5780 & 78 & 0,1949296 & 0,0957439 & - & 0,2941153 & 394,0591646 \\
\hline & Environmental performance & 850 & 10 & 0,0944319 & 0,0352961 & - & 0,1535677 & 36,1091977 \\
\hline \multirow{5}{*}{$\begin{array}{l}\text { 点 } \\
\sum_{\text {岃 }} \\
\text { 岀 }\end{array}$} & ROE & 2398 & 38 & 0,2174754 & 0,1008310 & - & 0,3341198 & 195,2319018 \\
\hline & ROA & 3141 & 35 & 0,1500577 & 0,0965490 & - & 0,2035663 & 124,7465017 \\
\hline & Stock Return & 231 & 4 & 0,3754860 & 0,2789167 & - & 0,4720554 & 19,4240554 \\
\hline & EPS & 512 & 6 & 0,2318748 & $-0,0017598$ & - & 0,4655094 & 74,1638148 \\
\hline & Profit Persistence & 348 & 5 & 0,0249013 & 0,0205210 & & 0,0292816 & 5,7786932 \\
\hline
\end{tabular}

The results of the sub-group performed on the measurement of the variables of financial performance, that is ROE, ROA, Stock Return, EPS, and Profit Persistence vary. Based on the sample of research data in accordance with predetermined criteria, the measurement of corporate finance performance that is widely used is ROE. Of the 60 studies used as samples, 34 studies used ROE as a measure of the corporate financial performance. Measurements using ROE, ROA, Stock Return, and Profit Performance indicate significant influence between CSRD and corporate financial performance in the same direction as the general meta-analysis (positive) results. The measurement of corporate financial performance using EPS indicates the insignificant influence between CSRD and the corporate financial performance because of the confidence interval shows positive and negative value, so hypothesis $3(\mathrm{H} 3)$ is accepted. These varied results indicate the effect of moderation effects between CSRD and corporate financial performance.

Measurement of CSRD variables with sample research data in accordance with predetermined criteria, CSRD measurement is widely used is CSRDi. From 60 studies with 88 independent variables obtained, 59 samples used CSRDi with 78 variables as CSRD measurements and 7 studies with 10 variables of environmental performance as CSRD measurements. CSRD measurements using CSRDi and environmental performance indicate a significant positive effect between CSRD and the corporate financial performance, in accordance with the general meta-analysis results. Based on the measurement of independent variables do not vary, so it can be concluded that there is no moderate effect 
between the influence of CSRD and the corporate financial performance. Based on this it can be said hypothesis $2(\mathrm{H} 2)$ is not accepted. Sub-group results based on the measurement of independent variables do not vary, so it can be concluded that there is no moderate effect between the influence of CSRD and corporate financial performance.

The Relation of Corporate Social Responsibility Disclosure to the Corporate Financial Performance. The results of the meta-analysis in this study were consistent with the individual studies conducted by Lougee et. Al. (2008), Lin et al. Al. (2009), and Tang et. Al., (2012) stating that CSRD has a positive effect on the corporate financial performance. In addition, the results of the study are also in accordance with individual research in Indonesia as in the study conducted by Ahmed et. (2012), Dahlia and Siregar (2008), Purnomo and Widianingsih (2012), and Pustikaningsih (2011) who took data from Indonesian companies so that the results of this study became more relevant.

Not only that, the relationship of the disclosure of CSR to the corporate financial performance will have the maximum impact for long-term sustainability of the corporate as investors and stakeholders will see how the company in conducting its operational activities and what has been disclosed and the corporate's contribution to stakeholders of the previous year and current year. By consistently making the CSRD, then investors and other stakeholders will give more trust to the corporate (Lin et al., 2009).

Based on the results of general meta analysis in this study proves that CSRD has a significant positive effect on the corporate financial performance, where it has proved that CSRD affects the corporate financial performance. After seeing the result of general meta analysis, it is necessary to do moderation test to find out whether there is moderate effect of CSRD relationship to corporate financial performance either influenced by measurement model of CSRD and also model of corporate financial performance measurement.

The relation of Corporate Social Responsibility Disclosure to the Corporate Financial Performance is Moderated by the Corporate Financial Performance Measurement Model. Based on the meta analysis, it is evident that the influence between CSRD and the corporate financial performance is moderated by the corporate financial performance measurement model. This can be seen from the inconsistency of meta sub-group results for the measurement of the corporate financial performance. This means that the measurement of the corporate financial performance affects the results of previous studies.

Based on the results of the moderating effects sub-group research, the positive results are significant in the general meta analysis is Return On Equity (ROE), Return On Assets (ROA), Stock Return, Earning Per Share (EPS), and profit persistence for the measurement model of corporate financial performance. Significant positive CSRD measurement models in accordance with general meta-analysis are the Corporate Social Responsibility Disclosure index (CSRDi) and environmental performance. These ratios can be considered for the corporate in disclosing the optimal CSRD to improve the corporate financial performance. Investors can also pay attention to how the corporate that has a good level of disclosure to produce maximum financial performance.

Sensitivity Analysis. The results of the publication status meta-analysis in Table 5.3. States there is no publication bias between published research and unpublished research. Consistent with the results of general meta-analysis, the average correlation analysis $(\bar{r})$ for publication research is 0.2065 , whereas for non-publicized research is 0.0023 .

Table 4 - Publication status meta-analysis

\begin{tabular}{|c|c|c|c|c|c|c|c|}
\cline { 2 - 8 } \multicolumn{1}{c|}{} & $\sum \mathrm{Ni}$ & $\mathrm{K}$ study & $\mathrm{r}$ & Min & to & Max & $\mathrm{x}_{\mathrm{k}-1}^{2}$ \\
\hline General Meta Analysis & 6630 & 88 & 0,18204526 & 0,085857472 & - & 0,27823304 & 436,0571951 \\
\hline Published & 5464 & 76 & 0,2065332 & 0,1234953 & - & 0,2895711 & 328,5776104 \\
\hline Unpublished & 1166 & 12 & 0,00237924 & $-0,2832450$ & - & 0,2880034 & 181,9191744 \\
\hline
\end{tabular}

The quality of the study is one of the things that can cause publication bias in the meta analysis. Based on these results can be concluded that the influence of CSRD on corporate financial performance is not influenced by the type of research, both published and unpublished. 
Discussion. The main purpose of meta-analysis research for the influence of CSRD on the corporate financial performance is to seek consistency from the relationship of both. In addition, meta analysis can also help to determine the causes of inconsistencies in previous studies due to differences in the model of measurement of dependent and independent variables. Based on the results of this study, it is generally found that the influence of CSRD on the corporate financial performance is positive, which means, with the increasing disclosure of CSRD by the corporate will be directly proportional to the improvement of corporate financial performance.

In accordance with the theoretical basis, the theory of stakeholders conveyed by Freeman (1983), this study successfully proves that CSRD is a disclosure provided by the corporate with the aim to inform investors and stakeholders that the corporate has contributed in maintaining the environment and accountability in its operational activities. The results support the research conducted by Ahmed et. Al. (2012); Dahlia and Siregar (2008); Lougee et. Al. (2008); Lin et. Al. (2009); Purnomo and Widianingsih (2012); Pustikaningsih (2011); And Tang et. Al. (2012).

In practice, the implications obtained from the results of this study, the management can use CSRD as a factor that can improve the corporate financial performance. Managers must be able to create an optimal report in terms of the type of dividends paid, the composition of the corporate earnings are distributed for dividends or as a reserve of corporate investment, as well as the time of dividend payout.

The measurement of CSRD variables and the corporate financial performance. The diversity of these types of measurement can be a cause of inconsistency of the research results on the relationship between the two variables. Therefore, this research tries to know what variables are relevant by using moderation effect test. Based on the result of moderation effect test, it is found that the variables that are relevant to the influence of CSRD and the corporate financial performance are CSRDi and environmental performance for measurement of CSRD and ROE, ROA, stock return, and profit persistence for measurement of corporate financial performance.

The implication, managers can focus on the six ratios, so as to maximize the corporate financial performance. Corporate Social Responsibility Disclosure index (CSRDi) is obtained from the amount of disclosure made by the corporate in the sustainability report issued by the corporate annually in accordance with the provisions issued by GRI. The more complete and clear sustainability report issued by the corporate, investors and stakeholders can assess how the level of corporate responsibility, and gain more trust and become additional value for the corporate itself. While CSRD is measured by environmental performance is one form of supervision, transparency efforts, and increased contribution in environmental management submitted by the Ministry of Environment, so the company in its operation should also consider for the corporate if it gets the rating PROPER is good.

With the high return earned by the company then investors will judge that the corporate performance is good and profit. On the other hand, earnings persistence is a profit that has an indicator of future earnings generated by the corporate repeatedly in the long run. The high level of profit persistence will attract more investors to invest in a corporate.

\section{CONCLUSION AND FURTHER RESEARCH}

This study aims to determine the effect of CSRD on corporate financial performance, then analyze and test variations of research results on the influence of CSRD and corporate financial performance in Indonesia. This study used a meta-analysis approach with a sample of 60 studies in Indonesia in 2000-2016. The results of this study suggest.

In general, CSRD can improve the corporate financial performance. The results of this study is in accordance with the theoretical basis, the theory of stakeholders conveyed by Freeman (1983), this study successfully proves that CSRD is a disclosure provided by the corporate in the form of a report that aims to inform investors and stakeholders that the corporate has contributed in maintaining the environment and accountability has been done by the corporate from its operational activities. The results support the research conducted 
by Ahmed et. Al., 2012; Dahlia and Siregar, 2008; Lougee et. Al., 2008; Lin et. Al., 2009; Purnomo and Widianingsih, 2012; Pustikaningsih, 2011; and Tang et. Al., 2012.

Based on the results of moderation effect test, the influence of CSRD on the corporate financial performance is influenced by the model of corporate financial performance measurement models. This is because the result of moderation effect test using the measurement of corporate financial performance is not consistent. This means that the relationship between CSRD and the corporate financial performance is weakened by one of the financial performance measurement models. Based on the results of these studies, it is evident that the inconsistency of previous research results due to differences in corporate financial performance measurement models.

During the research there are several things that become limitations:

Previous articles on the effects of CSRD and corporate financial performance do not show the overall research information, variable measurements and detailed statistical data, thereby reducing the number of samples that can be processed into meta analysis. Subsequent research is expected to use more research data with a more varied measurement model and complete statistical information, so it can know the ratio or other types of measurements that affect the corporate financial performance.

Research in Indonesia generally use CSRDi and environmental performance PROPER SRI KEHATI. Though there is one more measurement model of CSRD is ISO 26000 which is still rarely that research in Indonesia. Further research is expected to use ISO 26000 in viewing CSRD, so that the analysis of CSRD and corporate financial performance can use more varied measurement model.

\section{REFERENCES}

1. Ahmed, K., \& Courtis, J.K. (1999). Associations between Corporate Characteristics and Disclosure Levels in Annual Reposrts: A Meta Analysis. British Accounting Review, 31(1), 35-61.

2. Ahmed, S.U., Islam, M.Z., Hasan, I. (2012). Corporate Social Responsibility and Financial Performance Linkage-evidence from the Banking Sector of Bangladesh. Journal of Organizational Management, 1(1), 14-21.

3. Angela. (2015). Pengaruh Kinerja Lingkungan terhadap Kinerja Finansial dengan Pengungkapan Corporate Social Responsibility (CSR) sebagai Variabel Intervening. Skripsi. Fakultas Ekonomi Universitas Sanata Dharma. Yogyakarta.

4. Anggraini, Fr. Reni Retno. 2006. Pengungkapan Informas Sosial dan Faktor-Faktor yang Mempengaruhi Pengungkapan Informasi Sosial dalam Laporan Keuangan Tahunan (Studi Empiris pada Perusahaan-Perusahaan yang Terdaftar di Bursa Efek Jakarta). Simposium Nasional Akuntansi IX. Padang.

5. Anwar, R. (2005). Meta Analisis. Bandung: Fakultas Kedokteran Universitas Padjajaran.

6. Armstrong, Michael. 2014. Armstrong's Handboo of Human Resource Management Practice 13th Edition. Ashford Colour press Ltd : United Kingdom.

7. Athanasia, Smprini V. dan O.F. Maria. 2010. Financial Performance and Corporate Social Responsibility: An Empirical Investigation in the Banking Industry. International Hellenic University.

8. Belkaoui, Ahmed. 1976. The Impact of the Disclosure of the Environmental Effects of Organizational Behavior on the Market. Financial Management, 5(4), 26-31.

9. Brine, Matthew, R. Brown, dan G. Hackett. 2007. Corporate Social Responsibility and Financial Performance in the Australian Context. Corporations and Financial Services Division, the Australian Treasury, 47-58.

10. Chariri, A dan Firman A. J. 2009. "Retorika Dalam Pelaporan Corporate Social Responsibility: Analisis Semiotik Atas Sustainability Reporting Pt Aneka Tambang Tbk". Simposium Nasional Akuntansi XII Palembang 4-6 November 2009.

11. Criso'stomo, V. Lima, F.S. Freire, dan F.C. de Vasconcellos. 2011. Corporate Social Responsibility, Firm Value and Financial Performance in Brazil. Social Responsibility Journal, 5(3), 129-138. 
12. Dahlia, Lely dan Sylvia Veronica Siregar. 2008. Pengaruh Corporate Social Responsibility terhadap Kinerja Perusahaan (Studi Empiris pada Perusahaan yang Tercatat di Bursaa Efek Indonesia pada tahun 2005 dan 2006). Simposium Nasional Akuntansi XI. Pontianak.

13. Dowling, J. Dan Pfeffer. 1975. Organizational Legitimacy: Social Values and Organization Behaviour. Pacific Sociological Review, 18(1), 122-136.

14. Eipstein, M.J. dan M. Freedman. 1994. Social Disclosure and the Individual Investor. Accounting, Auditing and Accountability Journal, 7(4), 94-108.

15. Fahmi, Irham. 2011. Analisis Kinerja Keuangan. Bandung: Alfabeta.

16. Fanani, Zaenal. 2016. Research Study Literature Using Meta Analysis: Teori dan Aplikasi. Seminar Kolegial Pendidikan Profesional Berkelanjutan (PPL). Universitas Negeri Malang.

17. Freeman, R. Edward. 2004. Stakeholder Theory and "The Corporate Objecive Revisited". Organization Science, 15(3), 364-369.

18. Garcia, Meca E., dan J. P. Sanchez.2009. corporate Governance and Earnings Management: A Meta- Analysis. Corporate Governance: An International Review, 17(5),594-610.

19. Glass, G. 1976. Primary, Secondary, and Meta Analysis of Results. Educational Researcher, 5(10) 3-8.

20. Gray, R., R. Kouhy, dan S. Lavers. 1995. Corporate Social and Environmental Reporting. A Review of the Literature and a Longitudinal Study of UK Disclosure. Accounting, Auditing, and Accountability Journal, 8(2),47-77.

21. Hadi, Nor. 2014. Corporate Social Responsibility. Yogyakarta: Graha IImu.

22. Hunter, J.E., dan F.L. Schmidt. 1990. Methods of Meta Analysis : Correcting Error and Bias in Research Findings. Beverly Hills, CA:Sage.

23. Ikatan Akuntan Indonesia. 2007. Standar Akuntansi Keuangan. Jakarta: Salemba Empat.

24. Indrawan, Danu Candra. 2011. Pengaruh Corporate Social Responsibility terhadap Kinerja Perusahaan. Minor Theses. Faculty of Economy Diponegoro University. Semarang.

25. Jamali, Hisnol. 2014. Pengaruh Tata Kelola Perusahaan dan Tanggung Jawab Sosial terhadap Kinerja Keuangan dengan Efisiensi Usaha sebagai Variabel Mediasi. Dissertation. Faculty of Economic and Business Brawijaya University. Malang.

26. Lin, Chin Huang, Ho Li Yang dan Dian Yan Liou. 2009. The Impact of Corporate Social Responsibility on Financial Performance: Evidence from Business in Taiwan. Journal Technology in Societ, 31(1), 56-63.

27. Lougee, Barbara dan James Wallace. 2008. The Corporate Social Responsibility (CSR) Trend. Journal of Applied Corporate Finance, 20(1), 96-108.

28. Lyons, Larry C. 2003. Meta Analysis: Methods of Accumulating Results Acros Research Domains. George Washington University Medical Center: Washington DC.

29. Muntiah, Siti. 2013. Pengaruh Mekanisme Corporate Governance terhadap Kinerja Perusahaan (Studi Perusahaan Manufaktur yang Terdaftar di Bursa Efek Indonesia Periode 2010-2012). Jurnal Akuntansi, 1(1), 1-17.

30. Novriyanti, Vesy dkk. 2011. "Pengaruh Corporate Social Responsibility dan good corporate Governance terhadap Kinerja Perusahaan". Riau. FKIP-Universitas Riau.

31. O'Donovan, G. 2002. Environmental Disclosue in The Annual Report: Extending the Applicability and Predictive Power of Legitimacy Theory. Accounting, Auditing \& Accountability Journal, 15(3), 571-610.

32. Patten, Dennis M..1990. the Market Reaction to Social Responsibility Disclosures: The Case of the Sullivan Principles Signings. Accounting, Organizations, and Society Oxford, 15(6), 575-587.

33. Purnomo, P. Karin dan L.P. Widianingsih. 2012. The Influence of Environmental Performaance on Financial Performance with Corporate Social Responsibility (CSR) Disclosure as a Moderating Variable: Evidence from Listed Corporate in Indonesia. Review Intergrative Business \& Economics Research, 1(1), 57-69. 
34. Pustikaningsih, Adeng. 2011. Analisis Hubungan Corporate Social Responsibility (CSR) terhadap Kinejra Keuangan pada Perusahaan Jasa (Studi Kasus Perusahaan Jasa di D.I. Yogyakarta). Jurnal Pendidikan Akuntansi Indonesia. 9(2) 32-39.

35. Sarwono, J. 2011. Teori Analisis Korelasi. Diakses, http://www.jonathansarwono.info/ korelasi.htm.

36. Tang, Zhi, Clyde Eirikur Hull dan Sandra Rothenberg. 2012. How Corporate Social Responsibilit Engeagement Strategy Moderates the CSR - Financial Performance Relationship. Journal of Managemet Studies, 49(7), 1274-1303.

37. Untung, Hendrik Budi. 2009. Corporate Social Responsibility. Sinar Grafika: Jakarta.

38. Wijayanti, F.T. Sutaryo, and M.A. Prabowo. 2011. Pengaruh Corporate Social Responsibility terhadap Kinerja Perusahaan. Simposium Nasional Akuntansi XIV. Aceh. Universitas Syiah Kuala Banda Aceh.

39. Yaparto, Marissa, D. Frisko, and R. Eriandani. 2013. Pengaruh Corporate Social Responsibility terhadap Kinerja Keuangan pada Sektor Manufaktur yang Terdaftar di Bursa Efek Indonesia pada Periode 2010-2011. Jurnal IImiah Mahasiswa Universitas Surabaya, 2(1), 1-17. 